\title{
ШЛАКИ КОМБИНАТА «ПЕЧЕНГАНИКЕЛЬ» ДЛЯ СОЗДАНИЯ СУБСТРАТОВ - ПОЧВОЗАМЕНИТЕЛЕЙ (РЕЗУЛЬТАТЫ ОПЫТОВ ПО СОЗДАНИЮ ИСКУССТВЕННЫХ ФИТОЦЕНОЗОВ)
}

\author{
Горбачева Т.Т. ${ }^{1}$, Иванова Л.А. ${ }^{2}$ Макаров Д.В. ${ }^{3}$ \\ ${ }^{1}$ ФИЦККЦРАН, podzol_gorby@mail.ru \\ ${ }^{2}$ Полярно-альпийский ботанический сад-институт им. Н.А. Аврорина КНЦ РАН \\ ${ }^{3}$ Институт проблем промышленной экологии Севера КНЦ РАН
}

Металлургические шлаки и продукты их переработки находят широкое применение в экономике России, в т.ч. в таких направлениях улучшения экологической обстановки в регионах с высокоразвитым промышленным сектором [1], как:

(1) нейтрализация кислых шахтных вод при прекращении добычи руд;

(2) очистка грунтовых вод от токсичных загрязнителей;

(3) выработка твердеющих закладочных смесей при подземной отработке месторождений и закладке карьерных выемок;

(4) создание буферного или дренажного слоя при проведении рекультивационных работ;

(5) замена почвенного покрова или известкование почвогрунтов в биологическом этапе рекультивации.

Нами предложено новое направление использования в регионе металлургических шлаков медно-никелевого производства - химическая мелиорация и создание субстратов-почвозаменителей. Стандартные подходы к рекультивации земель, разработанные в целом для РФ, на Севере зачастую оказываются нерезультативными. Землевание как традиционный метод восстановления растительного покрова является малоэффективным в условиях действующего производства из-за быстрой деградации почвенного слоя, нанесенного на нарушенную территорию. В работе [2] авторами проведена оценка шлаков комбината «Печенганикель» по их пригодности для рекультивации в соответствии с требованиями ГОСТ 17.5.1.03-86 «Охрана природы Земли. Классификация вскрышных и вмещающих пород для биологической рекультивации». По результатам работы подтверждена возможность использования шлаков как компонентов смешанного химического мелиоранта. При этом отмечен уровень биодоступности питательных элементов в составе шлаков, приемлемый для создания растительного покрова. Однако ограничивающим фактором внедрения шлаков в практику рекультивации нарушенных земель региона признана их очень низкая влагоемкость, близкая к влажности завядания растений на техногенных землях Европейского Севера [6].

Качество, долговечность и устойчивость искусственно создаваемых посевных фитоценозов во многом зависят не только от качества семян/травосмеси, но и от условий, обеспечивающих их быстрое дружное прорастание, дальнейший интенсивный рост и развитие всходов. Поэтому первая фаза жизненного цикла злаковых растений при формировании растительного покрова является самой важной. В фазу прорастания семян и появления всходов происходит переход семян из состояния покоя к активной жизнедеятельности, начинающийся с их набухания и заканчивающийся появлением всходов. Фаза прорастания включает семь подфаз, которые проходят только при определенных условиях аэрации и в определенном диапазоне температур (от 1-3 до $10^{\circ} \mathrm{C}$ ) [5]. Тригерным механизмом начала прорастания семян является влажность субстрата, поэтому в период прорастания семян и появления всходов она не должна оставаться ограничивающим фактором.

Помимо высокой влагоемкости, субстрат должен быть воздухоемким - защищающим ростки от перепадов температур; легким - не препятствующим росту проростков, а также стерильным (свободным от патогенной микрофлоры, губительной для молодых всходов). Ограничивающим фактором прорастания семян является $\mathrm{pH}$ водной вытяжки, отсюда следует избегать как ее высокой кислотности (ниже 3.5), так и высокой щелочности (выше 8.0). Поэтому крайне важно, чтобы при взаимодействии материала, применяемого для создания почвоподобного субстрата, с водой в растворе создавалась буферная система, обеспечивающая поддержание $\mathrm{pH}$ на оптимальном уровне. В ходе выполнения работы авторами продолжено апробирование ранее разработанных методов соз- 
дания растительного покрова на основе вермикулитового субстрата, отвечающего всем приведенным выше требованиям.

Благодаря уникальным свойствам (стерильность, высокая влаго- и воздухоемкость, буферность (поддержание $\mathrm{pH}$ на уровне 7.0-7.5), способность с катионо- и анионообмену) вермикулит выполняет функции биологически активного почвоподобного материала. Его применение позволяет получать в короткие сроки (до 14 дней) высококачественную растительную дернину с заданным видовым составом и плотностью травостоя [3]. Субстрат производится из вермикулитового концентрата Ковдорского месторождения по инновационной запатентованной технологии [7]. Вермикулит широко применяют либо в как компонент почвосмесей, либо как основу для выращивания любых видов растений гидропонным способом. Субстраты на основе вермикулита используют для посева семян, черенкования, выращивания рассады, многолетнего культивирования овощных и декоративных растений, транспортировки и хранения сельскохозяйственной продукции (клубней, луковиц, корневищ), защиты растений от заморозков. Единственным серьезным ограничением широкого применения вермикулитового сырья для целей рекультивации является необходимость его термоактивации и отсюда относительно высокая цена. Одним из возможных направлений повышения эффективности применения инновационных технологий является поиск добавок, позволяющих снизить дозы внесения вермикулита без существенного снижения качества формирующегося растительного покрова. В качестве такой добавки предлагается использовать шлаки комбината «еченганикель».

Целью данной работы являлся выбор допустимых соотношений «шлаки медно-никелевого производства: водоудерживающий компонент (вермикулит)» для создания растительного покрова (искусственного фитоценоза).

\section{Материалы и методы исследования}

По результатам проведенного нами исследования [2] сделано предположение, что шлаки в сочетании с вермикулитом, обладающим высокой водоудерживающей способностью, могут найти применение не только как химический мелиорант, но и как субстрат-почвозаменитель при создании травяного покрова на нарушенных территориях. В 2012 г. были проведены лабораторные опыты по созданию растительного покрова на минеральных грунтах лежалых шлаков, отобранных на шлакоотвале комбината «Печенганикель». В работе в качестве водоудерживающей добавки использовали мелкодисперсный термоактивированный вермикулит марки Випон-2. Основные характеристики материала: размер гранул - 2-5 мм, влагоемкость - 5 мл/г, пористость - 98 \%, насыпная масса - 350-399 кг/м³ [1]. Вермикулитовые субстраты способны удерживать влагу в течение от 1 до 4 недель в зависимости от температуры окружающего воздуха. Это способствует сокращению поливов и расхода поливной воды.

Экспериментальные исследования проводились в апреле 2012 г. в лабораторных условиях. Растения выращивали в круглых пластиковых емкостях высотой 4.7 см с посевной площадью поверхности 0.95 дм², объемом 0.45 дм³ $^{3}$ На дно сосуда производили послойную укладку шлаков и вермикулита. Схема лабораторных опытов представлена в таблице 1 . Все слои увлажняли водой из расчета 10 л/ $\mathrm{M}^{2}$.

В качестве ценозообразователей использовали травосмесь из 4 видов злаковых растений: пырей сизый (Agropyron intermedium (Host.) Beauv.), овсяница красная (Festuca rubra L.), райграс пастбищный (Lolium perenne L.), тимофеевка луговая (Phleum pratense L.), взятые в соотношении 1:1:2:2 (по массе). Семена трав были приобретены в розничной торговле.

Емкости с растениями размещали стационарно, эксперимент проводили при естественном освещении. Интенсивность освещения в период проведения опытов в среднем составляла в пасмурные дни 6, в солнечные - 20 Клк, температура воздуха в помещении - 18-22 ${ }^{\circ}$, влажность воздуха $-60 \%$.

Статистическая обработка полученных результатов проводилась методами описательной статистики и однофакторного дисперсионного анализа. 


\section{Результаты и обсуждение}

Параметры сформированного фитоценоза приведены в таблице 1. Опыты по каждому варианту проводились в пяти повторностях.

Таблица 1. Влияние состава субстрата на параметры посевного фитоценоза.

\begin{tabular}{|c|c|c|c|c|c|c|c|c|c|}
\hline \multirow{3}{*}{  } & \multirow{3}{*}{ Субстрат } & \multicolumn{3}{|c|}{ Дата } & \multicolumn{5}{|c|}{$\begin{array}{c}\text { Средние значения } \\
\text { параметров }\end{array}$} \\
\hline & & \multirow{2}{*}{ 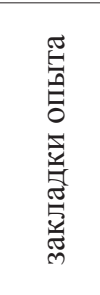 } & \multirow{2}{*}{ 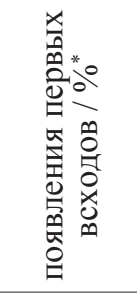 } & \multirow{2}{*}{ 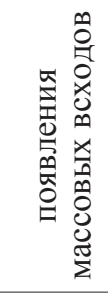 } & \multicolumn{2}{|c|}{$\begin{array}{c}\text { высота } \\
\text { травостоя, см }\end{array}$} & \multirow{2}{*}{ 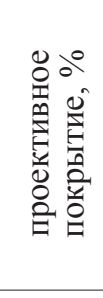 } & \multirow{2}{*}{ 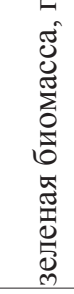 } & \multirow{2}{*}{  } \\
\hline & & & & & 13.04 & 17.04 & & & \\
\hline 1 & $\begin{array}{l}\text { шлаки }(1 \text { см })+ \\
\text { вермикулит }(1 \text { см })\end{array}$ & 06.04 & $10.04 / 10$ & 12.04 & 5.7 & 13.1 & 100 & 15.3 & 2.0 \\
\hline 2 & $\begin{array}{l}\text { шлаки }(2 \text { см })+ \\
\text { вермикулит }(1 \mathrm{~cm})\end{array}$ & 06.04 & $10.04 / 10$ & 12.04 & 5.5 & 13.9 & 100 & 15.7 & 3.0 \\
\hline 3 & $\begin{array}{l}\text { шлаки }(3 \text { см })+ \\
\text { вермикулит }(1 \text { см })\end{array}$ & 06.04 & $10.04 / 20$ & 12.04 & 5.4 & 12.4 & 100 & 16.2 & 4.0 \\
\hline 4 & $\begin{array}{l}\text { вермикулит (1см) } \\
\text { (контроль) }\end{array}$ & 06.04 & $10.04 / 30$ & 12.04 & 7.6 & 12.5 & 100 & 12.3 & 1.0 \\
\hline
\end{tabular}

Примечание: * - относительное число проростков, \%

\section{Появление первых всходов}

Независимо от варианта опыта появление первых зеленых всходов растений отмечено на 4-й день от начала эксперимента, массовых всходов - на 6-й день. Более стремительное появление проростков наблюдалось в контрольном варианте (вермикулит без добавки шлаков). Уровень прорастания семян в контроле составил $30 \%$, в то время как в вариантах с применением шлака - от 10 до $20 \%$ в зависимости от толщины слоя шлака.

Длина надземной части растений на ранней стадии развития была больше у растений в контрольном варианте: на 9-й день она достигла 7.6 см., а в вариантах со шлаком не превысила уровень 5.4-5.7 см.

\section{Проективное покрытие}

На 13 день сформированный травостой во всех вариантах имел 100\% проективное покрытие и хорошо развитую корневую систему. Корни растений полностью освоили субстраты и сформировали плотную травяную дернину (рис. 1).

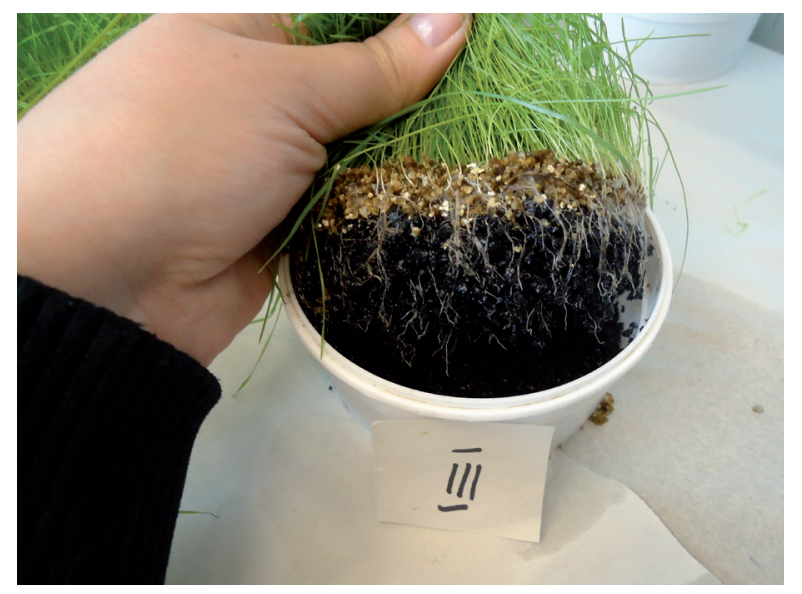

Рис. 1. Освоение двухслойного почвозаменителя корневой системой растений, вариант 3, верхний слой - вермикулит Випон-2; нижний - шлаки (3 см). 
Мощность дернины зависела от состава субстрата: наибольшая мощность дернины (4 см) отмечена в варианте 3 , где слой шлака имел максимальную в опытах толщину 3 см. Минимальная мощность дернины отмечена в контрольном варианте (монослой вермикулита). Вероятно, биодоступность питательных элементов в шлаке выше, чем в термовермикулите, что и сказалось на росте и развитии растений. К концу эксперимента высота растений во всех вариантах опыта сравнялась, а в варианте 1 и 2 даже несколько превысила этот показатель в контроле. Все это отразилось и на накоплении зеленой массы - она была существенно выше в вариантах с применением шлаков.

\section{Выводы}

В краткосрочном лабораторном опыте показано положительное влияние шлаков комбината «Печенганикеля» на накопление биомассы растительного покрова, что связано с наличием биодоступных форм питательных элементов в их составе;

Использование шлака с добавкой термовермикулита как водоудерживающего агента способствует ускоренному формированию качественных искусственных посевных фитоценозов даже в случае преобладания шлаков в составе смеси (3:1 по мощности слоя).

Планируется проведение оценки пролонгированности действия комплексного мелиоранта/ почвозаменителя при имитации аэротехногеной нагрузки в лабораторных условиях, а также подтверждение устойчивости фитоценоза при применении мелиоранта в полевом опыте.

\section{Литература}

1. Антонинова Н.Ю., Шубина Л.А. Использование техногенных отходов ГМК в природоохранных целях на предприятиях ГМК // Экология и промышленность России. 2015. № 10. С. 38-41.

2. Горбачева Т.Т., Иванова Л.А., Макаров Д.В. Шлаки «Печенганикеля» в решении экологических задач // XIV Всероссийская (с международным участием) Ферсмановская научная сессия, посвященная 100-летию со дня рождения д. г.-м.н. Козлова Е.К. Апатиты: Изд. КНЦ РАН. 2018 (данный сборник).

3. Иванова Л.А., Котельников В.А. Перспективы гидропонного выращивания растений в Мурманской области. Апатиты: Изд-во КНЦ РАН. 2006. 106 с.

4. Иванова Л.А., Котельников В.А. Полезная модель «Трубчатая наклонная печь для обжига вспучивающихся материалов»: Пат. № 55110, заявка № 2006105085, зарегестрировано в Госреестре полезных моделей РФ 27 июля 2006 г. № 21.

5. Обручева Н.В. Различная регуляция выхода семян из физиологического покоя и их прорастания // Физико-химические механизмы адаптации растений к антропогенному загрязнению в условиях Крайнего Севера: Годичное собрание общества физиологов растений России. Тезисы международной конференции. Апатиты. 2009. С. 248-250.

6. Федорец Н.Г., Соколов А.И., Шильцова Г.В., Германова Н.И., Крышень А.М, Антипина Г.С. Начальные стадии формирования биогеоценозов на техногенных землях Европейского Севера. Петрозаводск: Карельский научный центр РАН, 1999. 74 с.

7. Kotelnikov V.A., Ivanova L.A. (en) Method for biologically recultivating industrial wastelands. Pub. No.: WO/2011/084079. International Application No.:PCT/RU2010/000001. Publication Date: 14.07.2011. International Filing Date: 11.01.2010. IPC: A01B 79/02 (2006.01), A01G 1/00 (2006.01), A01G 31/00 (2006.01). 